\title{
Making sense of Piketty's 'fundamental laws' in a Post-Keynesian framework: the transitional dynamics of wealth inequality
}

\author{
Stefan Ederer* \\ Austrian Institute of Economic Research (WIFO), Vienna and Vienna University of Economics and \\ Business (WU), Austria \\ Miriam Rehm \\ University of Duisburg-Essen, Germany and Vienna University of Economics and Business (WU), Austria
}

If Piketty's main theoretical prediction ( $r>g$ leads to rising wealth inequality) is taken to its radical conclusion, then a small elite will own all wealth if capitalism is left to its own devices. We formulate and calibrate a Post-Keynesian model with an endogenous distribution of wealth between workers and capitalists which permits such a corner solution of all wealth held by capitalists. However, it also shows interior solutions with a stable, non-zero wealth share of workers, a stable wealth-to-income ratio, and a stable and positive gap between the profit and the growth rate determined by the Cambridge equation. More importantly, simulations show that the model conforms to Piketty's empirical findings during a transitional phase of increasing wealth inequality, which characterizes the current state of high-income countries: the wealth share of capitalists rises to over 60 per cent, the wealth-to-income ratio increases, and income inequality rises. Finally, we show that the introduction of a wealth tax as suggested by Piketty could neutralize this rise in wealth concentration predicted by our model.

Keywords: Post-Keynesian, model, wealth, saving, inequality, Piketty, simulation

JEL codes: $C 63, D 31, E 12, E 21$

\section{INTRODUCTION}

Thomas Piketty's best-selling book, Capital in the Twenty-First Century (Piketty 2014), triggered a renewed interest in empirical research regarding the accumulation and distribution of wealth, and a lively debate about their causes and consequences. Wealth determines income, power and opportunities, and lies at the very heart of

* Corresponding author: Email: stefan.ederer@wifo.ac.at. We would like to thank Marc Lavoie, Tom Palley, and seminar participants at the FMM Conference, the Momentum Conference, the Austrian Chamber of Workers Vienna and the Institute for Ecological Economics at the Vienna University of Business and Economics as well as two anonymous referees for suggestions. The usual disclaimer applies. 
economic inequalities. Understanding the dynamics of wealth accumulation and distribution is thus crucial to tackle these inequalities.

In a nutshell, Piketty's (2014) theoretical argument is that, since the profit rate is usually higher than the growth rate in an economy (an empirical regularity which he finds for most countries and time periods for which his detailed archival work provides data), over time wealth increases faster than income. This entails a more unequal distribution of income, because the share of profits increases and wealth ownership and capital income are more concentrated than labour income. A rising income inequality finally feeds back into a more unequal distribution of wealth, so that wealth will be ever-increasingly concentrated in the hands of a small elite. Piketty (2014) nevertheless carefully balances such a radical interpretation of his analysis with theoretical counter-tendencies, historical analysis and empirical work.

Empirically, Piketty (2014) provides extensive data on the historical evolution of wealth-to-income ratios, wealth, and personal income distribution. He shows that the wealth-to-income ratio has risen, and that wealth and income have become more unequally distributed in high-income countries since about the 1980s. Regarding the profit rate and the growth rate, he argues that they have been largely stable over the long run, but that the former is empirically higher than the latter.

The reception of the book in Post-Keynesian economics has been mixed. On the one hand, Post-Keynesian economists recognize the empirical contributions of the book: the collection of historical data and the carving out of observable patterns therein (Rowthorn 2014; Rehm and Schnetzer 2015; King 2017). On the other hand, Piketty's Neoclassical theoretical framework by which he explains the dynamics of wealth and income inequality has attracted the criticism of Post-Keynesian economists, in whose theoretical frameworks distribution has long played a major role (for example, Galbraith 2014; Palley 2014; López-Bernardo et al. 2016a). Based on the Cambridge equation (Pasinetti 1962), they point out that the wealth distribution in the long run can be stable, a statement that is clearly in contradiction to a reading of Piketty that takes his Neoclassical theory to its radical logical conclusions. Ederer and Rehm (2020) show that the empirical distribution of wealth is still less unequal than the one implied by a parameterized Post-Keynesian model.

Both Piketty and Post-Keynesians, however, consider the transition phase - the world in which this and the next generation lives - as the relevant reference point for economic analysis. The development of income and wealth inequality over the next decades matters. The goal of this paper is to develop a Post-Keynesian model that explains this short-run dynamic of wealth accumulation and distribution, for which Piketty (2014) presents abundant empirical evidence. We therefore do not focus on the long-run equilibrium steady state. In the 'transitional phase', that is, when the wealth share of capitalists is below its long-run equilibrium value, a rising wealth-to-income ratio and increasingly unequal distributions of wealth and income can be described well by our Post-Keynesian model. Due to its focus on the long run, these short-run dynamics have not been investigated by Piketty's Post-Keynesian critics so far. This paper intends to close this gap.

To do so, we build a Post-Keynesian model in the tradition of Bhaduri and Marglin (1990) which incorporates an endogenous wealth distribution. We extend the model by blended incomes of workers and capitalists, differential rates of return, and capital gains. We show that a stable wealth share is a likely outcome in the long run, and both the euthanasia and the triumph of the rentier are special cases, and thus we reiterate the critique of Piketty's hypothesis of an ever-increasing wealth concentration. Furthermore, we use the model to explain a 'transitional dynamic' that resembles 
the empirical evidence presented by Piketty and his projections to the future. A rising wealth-to-income ratio, rising wealth and income inequality and a profit rate that is higher than the growth rate of the capital stock (and thus income) are all consistent with our extended Post-Keynesian model.

Piketty, like many Post-Keynesians, is concerned with the factors that might disturb this long-run capitalist path towards an equilibrium. He worries that the world of increasing inequality, which his data describes, might be prone to upheavals, social unrest and war. This is why Piketty focuses on finding democratic, political solutions - such as a wealth tax - to the ever-rising importance of inherited wealth over wealth acquired through work. We follow his suggestion and implement a wealth tax in the model and show that this stabilizes both wealth and income inequality.

The structure of the paper is as follows. The literature review in Section 2 discusses both Piketty and his Post-Keynesian critics, as well as the Post-Keynesian models of distribution. Section 3 describes the model and its short- and long-term equilibria in detail. Section 4 presents the transitional dynamics of the model. Section 5 discusses the model extensions. Section 6 presents a numerical simulation of both short-run dynamics and the long-run equilibrium. Section 7 discusses the effects of a wealth tax. Section 8 concludes.

\section{PIKETTY AND THE POST-KEYNESIANS}

Piketty (2014)'s theoretical framework, formally elaborated in Piketty and Zucman (2014), consists of two fundamental laws and a fundamental contradiction of capitalism. Piketty's first law states that the share of income from capital in total national income is equal to the rate of profit times the wealth-income ratio, or $\alpha=r \times \beta$, an accounting identity (Piketty 2014, p. 52). The second law is the Harrod-Domar equation (Piketty and Zucman 2014, p. 1274) in which the ratio of wealth to income equals the ratio of the saving rate to the growth rate. In Piketty's denotation, $\beta=s / g$ (Piketty 2014, p. 166). Piketty's fundamental contradiction argues that wealth (which he treats synonymously with capital) increases faster than income if the profit rate is higher than the growth rate of GDP, that is, if the oft-cited formula $r>g$ holds (Piketty 2014, p. 571). Piketty's analysis is based on a Neoclassical production function, which assumes that the elasticity of substitution between labour and capital is higher than one (Piketty and Zucman 2014, p. 1271), and the rate of profit is technologically determined (Piketty and Zucman 2014, p. 1270). The profit rate and Piketty's $\beta$ yield the profit share.

Empirically, Piketty's work is ground-breaking in the breadth and depth of his coverage of both wealth and income time series. In particular, he documents an increasingly unequal distribution of wealth (Piketty 2014, pp. 336ff), rising wealth-to-income ratios (ibid., pp. 164ff), and an increasing concentration of the personal income distribution (ibid., pp. 304ff) in Europe and the US, roughly since the 1980s. He also documents a slowing growth rate (ibid., pp. 93ff) and a declining rate of return (ibid: 199ff) over that time horizon, even though he sees both as roughly stable over the long run. Crucially for his argument, he finds his 'fundamental contradiction' of capitalism to be empirically valid for most economies and historical periods, that is, the profit rate to be higher than the growth rate (ibid., pp. 359ff). Piketty sees a number of positive feedback mechanisms, which lead to an ever-increasing inequality in the distribution of income and wealth. Barring political intervention and notwithstanding his detailed discussion of institutional and systemic factors in the wealth distribution, following 
this train of thought to its logical conclusion means that Piketty's main prediction is that all wealth will be concentrated in the hands of a very small elite.

The Post-Keynesian and Structuralist reception of Piketty's work has been largely sceptical. King's (2017) comprehensive review summarizes the arguments (of Neoclassical, Austrian and Post-Keynesian economists) in nine over-arching points of critique. These range from differences in opinion regarding the relevance of wealth inequality and the suggested policy conclusions, empirical disagreements and theoretical critiques, the latter including the importance of institutions and of low-income countries. Relevant for this paper are the two critiques that (i) 'Piketty uses the wrong (neoclassical) theory' (ibid., p. 7) and (ii) that the 'predicted increase in wealth is implausible' (ibid., p. 3).

Regarding the first point, many Post-Keynesian and Structuralist economists criticized Piketty for using a Neoclassical framework. Piketty (2014, pp. 230ff) misrepresents the Cambridge capital controversy of the 1950s and 1960s (Galbraith 2014; Palley 2014; López-Bernardo et al. 2016a), which showed that Neoclassical economics is logically inconsistent in its valuation of capital, since the value of capital is simultaneously determined by and determines the rate of profit. Relative prices cannot reflect in general a measure of the scarcity of inputs, and capital is itself a produced commodity (Harcourt 1972; Felipe and McCombie 2013). Connected to this is the critique of Piketty's conflation of wealth and capital. In particular, Post-Keynesians and Marxists objected to treating housing wealth as productive capital, measuring wealth at highly volatile market prices untethered from 'fundamental' values (Duménil and Levy 2014; Rowthorn 2014). ${ }^{1}$

The bulk of Post-Keynesian criticism was directed at the second point (Michl 2014; Rowthorn 2014; Taylor 2014; van Treeck 2015; López-Bernardo et al. 2016a). As discussed, from Piketty's fundamental laws and in particular the inequality $r>g$ follows a long-run dynamics of wealth accumulation that leads to an ever-increasing share of wealth concentrated in the hands of capitalists. Treating the variables as independent, van Treeck (2015) numerically illustrates that the profit rate exceeding the growth rate is not a sufficient condition for the wealth-to-income ratio and inequality continues to rise indefinitely. Differential saving rates of households with different positions in the income distribution are a necessary precondition for Piketty's conclusion to hold, and the wealth distribution is highly sensitive to changes in these differential saving rates.

Based on Pasinetti's Cambridge equation $s_{r} r=g$ (that is, the equilibrium growth rate equals the saving rate of capitalists times the profit rate), Taylor (2014) argues that the two corner solutions, euthanasia and the triumph of the rentier, as well as an interior solution, are all possible results. He focuses on the interaction between the wealth share of capitalists, capacity utilization and the profit share, and points out that the feedback mechanisms between these variables can stabilize or destabilize the system, depending on the structure of the economy. He shows that a rising wealth share entails the possibility of a rising profit share and chronic underutilization of production capacities and stagnation in the long run, if the profit share responds strongly positively to an increase in the wealth share.

López-Bernardo et al. (2016a) also focus on the long run and the Cambridge equation. They argue that the profit rate must necessarily always be greater than the growth rate, provided that capitalists' savings rate is less than unity (that is, they consume a certain share of their income). Piketty's empirical finding that $r$ is greater than $g$ is

1. We briefly address this 'valuation problem' in the model section, and take the larger point regarding productive (rather than total) capital on board in the formulation of our model. 
thus fully consistent with a stable income distribution and, by extension, a stable wealth distribution. Only if the profit rate exceeds the ratio of the growth rate and the saving rate of capitalists will there be a redistribution from wages to profits, and thus a rising profit share and ultimately, a rising concentration of wealth. Furthermore, although individual capitalists can increase their rate of accumulation by saving more, capitalists as a whole cannot, because an increase in the saving rate would inevitably entail a fall in the profit rate. López-Bernardo et al. (2016a) argue that Piketty overlooked this 'fallacy of composition', even though he explicitly discusses (but dismisses by referring to technology) its relevance (Piketty 2014, pp. 215ff). However, they point out that Piketty's cumulative feedback mechanism between accumulation and wealth concentration is indeed valid when it comes to personal income distribution, in particular among capitalists, because they have no access to wage income in a simple formulation. ${ }^{2}$

Post-Keynesian models are well suited for the analysis of both short- and long-run dynamics of wealth accumulation and distribution. They have long been used to investigate the distribution between labour and capital in the wage-/profit-led debate (Bhaduri and Marglin 1990; Barbosa and Taylor 2006; Stockhammer and Ederer 2008; Stockhammer et al. 2009; Lavoie and Stockhammer 2013; Kiefer and Rada 2015) and the distribution of personal income (Lavoie 2009; Carvalho and Rezai 2016; Palley 2017a). It is therefore indeed vexing that Piketty's writing shows no reception of the extensive Post-Keynesian body of literature on the theory of distribution.

Two seminal Post-Keynesian models of the distribution of wealth are Palley (2012; 2017b) and Taylor et al. (2015). In Taylor et al.'s (2015) model, workers receive blended wage and profit income. The model incorporates capital gains due to its empirical relevance in the US. Taylor et al. (2015) simulate a wealth concentration ratio of about 60 per cent - the top 1 per cent owns roughly 60 per cent of total wealth. Wealth is split between 'the rich' and 'middle-class workers', as the 'bottom 60 per cent' empirically do not own any wealth. Palley's (2012) model, which builds on Dutt (1990), also includes an endogenous wealth distribution. The paper permits doubly blended income sources: both workers and capitalists receive work and profit income in a Post-Keynesian framework. The parameters influencing the personal income distribution (and growth) are the functional income distribution, the distribution of the wage bill between workers and capitalists, and the distribution of wealth between workers and capitalists. The latter, in turn, depends on the differential propensities to save. Finally, Ederer and Rehm (2020) develop and calibrate a Post-Keynesian model with an endogenous wealth distribution and differential returns to wealth between workers and capitalists. Compared to the current empirical distribution of wealth, the model predicts that the share of capitalists in total wealth will rise in all European countries for which they have data. Post-Keynesian models have paid less attention to the transitory dynamics for the phase during which the wealth share and the functional and personal income distribution differ from their (long-run) equilibria. The differential equations often used by the profit-led strand of the literature (and their concomitant vector autoregression (VAR) analyses) lend themselves to investigating these transition phases. Indeed, Taylor (2014) derives a differential equation for the wealth share. However, the paper then focuses on stable and unstable equilibria, while pointing to possible feedback mechanisms between the distribution of wealth with the profit share and capacity utilization.

2. Meade (1964) points out this disadvantage. Pasinetti (1974) argues that the thriftiest group among capitalists will eventually dominate the others, as noted by Taylor (2014). We return to this point in the following section. 
A recent paper by Petach and Tavani (2020) uses differential equations to simulate the transition phase before a Piketty-style triumph of the rentier in a Post-Keynesian model of microfounded differential saving rates and induced technical change.

This paper extends the model of Ederer and Rehm (2020), which follows the PostKeynesian tradition along the lines of Dutt (1990), Palley (2012; 2017b) and Taylor et al. (2015) with an endogenous wealth distribution in a two-class economy. The question we are asking is whether Piketty's empirical evidence regarding a rising wealth share for decades can be integrated into a Post-Keynesian model, which permits interior solutions for the wealth distribution. The main aim is to investigate the transition phase between short- and long-run dynamics of wealth accumulation and distribution, and thereby contribute to closing this gap in the Post-Keynesian literature of growth models.

\section{A MODEL OF THE WEALTH DISTRIBUTION}

The model is a standard two-class, Post-Keynesian formulation in the tradition of Bhaduri and Marglin (1990), drawing on Dutt (1990), Palley (2012; 2017b) and Taylor et al. (2015) and closely following Ederer and Rehm (2020). ${ }^{3}$ It therefore makes the following usual assumptions: growth is endogenous (in contrast to Piketty's Neoclassical model); labour supply adapts to labour demand; and we abstract from depreciation. We introduce four innovations: (i) wealth is accumulated through saving; (ii) blended wage and capital income goes to both workers and capitalists; (iii) beyond differential savings rates, workers and capitalists also have differential returns on their assets; and (iv) firms save and accumulate wealth, which is passed on to owners of shares via capital gains. This section introduces a basic version of the model, and Section 5 includes extensions (ii) to (iv).

\subsection{Basic model}

In the basic formulation of the model, income $Y$ is divided between total profits $R$ and the wage bill $W$ according to the (exogenous) functional income distribution $\pi$ (the profit share). ${ }^{4}$ This assumption contrasts with Piketty's Neoclassical model, where the profit share is endogenous.

$$
\begin{gathered}
R=\pi Y \\
W=(1-\pi) Y
\end{gathered}
$$

All wages accrue to workers in the simple version of the model. Income of capitalists (subscript $r$ ) thus amounts to profits $R$ on their share of productive wealth $z$. Workers (denoted by subscript $w$ ) also receive a part of profits $R$ proportional to their share of

3. The model is briefly restated here for the convenience of the reader, since we discuss the solution and the relevance of our analytical assumptions relating to Piketty's theoretical and empirical definitions in detail.

4. In contrast to the majority of Post-Keynesian models, we abstract from an exogenously rising profit share for reasons of tractability, because our focus here is on wealth inequality. However, the inclusion of a rising profit share would likely only shift the equilibrium wealth share upwards, that is, make the distribution more unequal. 
wealth ownership $(1-z)$, which together with wages make up the total income of workers $Y_{w}$.

$$
\begin{gathered}
Y_{r}=z R \\
Y_{w}=W+(1-z) R
\end{gathered}
$$

We follow Post-Keynesian convention by assuming a positive differential between savings rates of capitalists $s_{r}$ and workers $s_{w}$. Per definition, consumption propensities of workers and capitalists multiply with their respective incomes for total consumption $C$.

$$
C=\left(1-s_{w}\right) Y_{w}+\left(1-s_{r}\right) Y_{r}
$$

The investment equation is formulated according to the standard Post-Keynesian functional form in the Bhaduri-Marglin tradition, that is, growth of the capital stock $K$ depends on capacity utilization $u$ and the profit share $\pi$. This formulation allows for both wage-led and profit-led demand growth regimes, depending on the values of the parameters $\beta_{1}$ and $\beta_{2}$ and the saving rates.

$$
I=\left(\beta_{0}+\beta_{1} u+\beta_{2} \pi\right) K
$$

The aggregate goods market is in equilibrium, output equals demand. Since we abstract from all sectors other than households and firms, total demand consists of consumption and investment. ${ }^{5}$

$$
Y=C+I
$$

In order to de-trend income, profits and investment, we follow convention by normalizing them to the capital stock. This yields stable solutions for capacity utilization $u$, the profit rate $r$ and the growth rate of the capital stock $g$.

$$
\begin{gathered}
u=\frac{Y}{K} \\
r=\frac{R}{K}=\pi u \\
g=\frac{I}{K}
\end{gathered}
$$

The only asset in the model is productive wealth $V$ owned by households, which is equal to the capital stock $K$ :

$$
V=K
$$

5. The abstraction from government and an external sector is in line with Piketty (2014), who in much of his work omits them on empirical grounds, following careful examination of their importance and valuation problems. 
The ownership of (productive) capital entitles receipt of the corresponding share in profits. Both workers and capitalists accumulate wealth through savings. The level of savings is the difference between income and consumption.

In focusing on productive capital, we take on board an important strand of criticism of Piketty's Neoclassical basis, discussed in Section 2, even though we appreciate Piketty's argument that wealth categories are to a certain degree fungible. Departing from total wealth as measured in microeconomic surveys introduces a potential wedge between Piketty's and our empirical results, since the critiques were not solely based on theoretical arguments regarding unproductive capital, but also revolved around a rising empirical importance of housing wealth as a share of total private wealth (Duménil and Levy 2014). Our model is conceptually based on capital (rather than wealth), since it is adapted from a framework which focuses on productive investment and growth. Because productive wealth is distributed more unequally (that is, housing is distributed more equally), our simulations are on the conservative side as we are more likely to find Piketty's extreme inequality.

In order to trace the behaviour of the model compared to Piketty's empirical evidence, we include the above-mentioned wealth share of capitalists $z$, the ratio of capitalists' to workers' income, as a measure for the personal class-based income distribution $\theta$ in the model, and the wealth-to-income ratio $x$. Even though the latter is simply defined as the inverse of capacity utilization $u$, we include it as a variable here, since it plays such an important role in Piketty's argument.

$$
\begin{gathered}
z=\frac{V_{r}}{V} \\
x=\frac{K}{Y}=\frac{1}{u} \\
\theta=\frac{Y_{r}}{Y_{w}}
\end{gathered}
$$

Table 1 shows the stock-flow matrix of the model. A plus sign denotes a source of funds, a minus sign is a use of funds, and rows and columns sum to zero. Firms pay wage income to workers (row 3), and distribute profits (row 4), which both workers and capitalists receive. Workers and capitalists consume their income (row 1), and firms invest (row 2). Both workers and capitalists save and thus accumulate

Table 1 Stocks and flows in the Post-Keynesian model with endogenous wealth distribution

\begin{tabular}{lcccccc}
\hline & \multicolumn{2}{c}{ Households } & & \multicolumn{2}{c}{ Firms } & \\
\cline { 2 - 3 } & Workers & Capitalists & & Current & Capital & Total \\
\hline Consumption & $-C_{w}$ & $-C_{r}$ & & $+C$ & - & 0 \\
Investment & - & - & & $+I$ & $-I$ & 0 \\
Wages & $+W$ & - & & $-W$ & - & 0 \\
Profits & $+R_{w}$ & $+R_{r}$ & & $-R$ & - & 0 \\
\hline Wealth & $-\Delta V_{w}$ & $-\Delta V_{r}$ & & - & $+\Delta K$ & 0 \\
\hline Total & 0 & 0 & & 0 & 0 & 0 \\
\hline
\end{tabular}

Source: Own elaboration. 
wealth in the form of productive capital (row 5). Households' savings finance firms' investment (column 4).

\subsection{Short-run equilibrium}

The short-run solution of the model assumes wealth shares to be constant, since wealth accumulates over long time periods. Capacity utilization, the profit rate and the growth rate adjust simultaneously, so that the equilibrium in the aggregate goods market (that is, the IS condition) is fulfilled for any wealth share of capitalists $z$. The short-run solutions for these three variables thus depend on the distribution of wealth:

$$
\begin{gathered}
u^{*}=\frac{\beta_{0}+\beta_{2} \pi}{s_{w}+\left(s_{r}-s_{w}\right) \pi z-\beta_{1}} \\
r^{*}=\frac{\beta_{0} \pi+\beta_{2} \pi^{2}}{s_{w}+\left(s_{r}-s_{w}\right) \pi z-\beta_{1}} \\
g^{*}=\frac{\left(\beta_{0}+\beta_{2} \pi\right)\left[s_{w}+\left(s_{r}-s_{w}\right) \pi z\right]}{s_{w}+\left(s_{r}-s_{w}\right) \pi z-\beta_{1}} .
\end{gathered}
$$

In particular, a higher wealth share of capitalists lowers capacity utilization, the profit rate and the growth rate of the capital stock. The reason is that a higher wealth share of capitalists transfers profit income to capitalists, which depresses total consumption due to capitalists' higher saving rate. The effect of the wealth distribution on these variables hinges on the differential saving rates.

Contrary to a rise in the profit share, which can either raise or reduce the growth rate (depending on whether growth is wage-led or profit-led), a rise in the wealth share unambiguously depresses growth, since consumption decreases and there is no counteracting effect on investment. The latter is determined by the profitability of firms, not by the distribution of profits among workers and capitalists. Note that the profit rate is more sensitive to the wealth share than the growth rate, because its effect on the latter works indirectly via capacity utilization. This is the reason why the profit rate decreases faster than the growth rate when the wealth share rises, and the two variables will eventually fulfil the Cambridge equation (see below).

Since the wealth-to-income ratio $x$ is the inverse of capacity utilization, it increases the more wealth is concentrated in the hands of capitalists. Likewise, ${ }^{6}$ the personal income distribution as measured by the ratio of income of capitalists to the income of workers, $\theta$, is more unequal when the wealth share of capitalists is high, because a higher share of profits accrues to capitalists in that case.

$$
\begin{gathered}
x^{*}=\frac{s_{w}+\left(s_{r}-s_{w}\right) \pi z-\beta_{1}}{\beta_{0}+\beta_{2} \pi} \\
\theta^{*}=\frac{\pi z}{1-\pi z}
\end{gathered}
$$

6. By plugging equations (1) and (2) into equations (3) and (4), and simplifying equation (14). 


\subsection{Long-term equilibrium}

Over time, both capitalists and workers accumulate wealth until the wealth share adjusts to its long-term equilibrium. Pasinetti's (1962) Cambridge equation $s_{r} r=g$ implies that the wealth share is stable when capitalists save exactly the amount that corresponds to their share in the increase in total capital (Palley 2012; 2017b; Taylor 2014). Consequently, Palley (2017b) points out that the Cambridge equation should be interpreted as an 'ownership equilibrium condition', since capitalists must save just enough to maintain their ownership share.

Since both the profit rate and the growth rate depend on the wealth share of capitalists, $z$, we get a long-run equilibrium value for the wealth distribution:

$$
z^{* *}=\frac{s_{r} \pi-s_{w}}{\left(s_{r}-s_{w}\right) \pi}
$$

As long as the difference between the saving rates of workers and capitalists is sufficiently high, the equilibrium value for $z$ is positive. The (long-run) distribution of wealth only depends on the differential saving rates and the profit share. Capitalists' long-run equilibrium wealth share $z^{* *}$ is higher: (i) the higher the profit share, (ii) the higher the saving rate of capitalists, and (iii) the lower the saving rate of workers. It does not, however, depend on the growth rate (that is, on the parameters of the investment equation), which contradicts Piketty's argument. In the long-run equilibrium, in our model the wealth share is constant, so each class has to save the exact amount that keeps their wealth share constant, independent of how slowly or how quickly the economy grows.

There are two corner solutions for the wealth share: (i) If workers do not save at all, all wealth will (naturally) be concentrated in the hands of capitalists $(z=1)$. In this case, the share of total income going to profits is the only determinant of the distribution of income. (ii) If capitalists do not save, it is self-evident that eventually all wealth will belong to workers $(z=0)$. Furthermore, if the two saving rates are equal $\left(s_{w}=s_{r}\right)$, the model has no meaningful solution for $z$. All wealth would be concentrated in the hands of workers, if capitalists have no access to wage income. ${ }^{7}$

The long-run solutions for capacity utilization, the profit rate and the growth rate are:

$$
\begin{gathered}
u^{* *}=\frac{\beta_{0}+\beta_{2} \pi}{s_{r} \pi-\beta_{1}} \\
r^{* *}=\frac{\left(\beta_{0}+\beta_{2} \pi\right) \pi}{s_{r} \pi-\beta_{1}} \\
g^{* *}=\frac{s_{r}\left(\beta_{0}+\beta_{2} \pi\right) \pi}{s_{r} \pi-\beta_{1}} .
\end{gathered}
$$

Note that they are now independent from workers' saving rate. The Kaleckian principle, that 'capitalists earn what they spend' (Kalecki 1971) applies here in a broader sense,

7. Meade (1964) points this out; see also Taylor (2014). 
that is, that a higher saving rate of capitalists would diminish capacity utilization, the profit rate and the growth rate in equilibrium.

The long-run solutions for the wealth-to-income ratio and personal income distribution are

$$
\begin{aligned}
x^{* *} & =\frac{s_{r} \pi-\beta_{1}}{\beta_{0}+\beta_{2} \pi} \\
\theta^{* *} & =\frac{s_{r} \pi-s_{w}}{s_{r}(1-\pi)} .
\end{aligned}
$$

The personal income distribution also does not depend on the growth rate, but only on the profit share and the two saving rates. The wealth-to-income ratio on the other hand is higher, the lower the growth parameter $\beta_{0}$. This is in line with Piketty's argument that slow economic growth would raise $x$. Nevertheless, it has no impact on the distribution of wealth.

For the wealth-to-income ratio, Piketty's second fundamental 'law' (which Piketty and Zucman 2014 refer to as an accounting identity (p. 1274) and call the 'HarrodDomar-Solow formula' (p. 1257)) is fulfilled:

$$
x^{* *}=\frac{s}{g}
$$

where $s=s_{w}[(1-\pi)+\pi(1-z)]+s_{r} \pi z$ is the aggregate saving rate of the economy. ${ }^{8}$ In contrast to Piketty, however, as noted above, in our model the aggregate saving rate and the growth rate adjust endogenously through the change in the wealth share until they reach the long-run equilibrium. In the Post-Keynesian model, the wealth-toincome ratio and the personal income distribution are thus determined simultaneously with all the other (short-term) variables for any wealth share $z$.

It should be mentioned that one of Piketty's main theoretical repercussions of a rising wealth-to-income ratio is that the profit share rises, if the elasticity of substitution between labour and capital is greater than one. In the Post-Keynesian model, we follow convention and treat the profit share as exogenous. In contrast to Piketty's model, it is the profit rate that varies according to changes in capacity utilization. For Post-Keynesians, the profit share is determined by the power of workers and capitalists, which has significantly shifted in the direction of the latter since the 1980s. The deregulation of trade and capital flows as well as of financial markets and institutional changes brought labour onto the defensive; the result was a secular rise of the profit share.

Nevertheless, the profit share can also be endogenously determined within the model. Taylor (2014) briefly discusses the stabilizing and destabilizing mechanisms in such a model. The outcome, however, is ambiguous. While the profit share in such a model increases along with a rising wealth share, its long-run stability depends on the parameters of the model. For a wide range of values, a stable long-run equilibrium wealth share is very likely, so that the results of the abovementioned analysis remain valid. However, there is also the possibility of an 'explosive trajectory' where, at its end, all wealth is concentrated in the hand of capitalists. This would

8. Note that ${ }^{I} /{ }_{Y}=S /{ }_{Y} \rightarrow^{I} / K^{K} /{ }_{Y}=S / Y \rightarrow g x=s$. 
obviously validate Piketty (2014)'s predictions. To examine the dynamics of such a model is, however, beyond the scope of this paper.

\section{TRANSITIONAL DYNAMICS}

Another way to derive the Cambridge equation is to take the derivatives of the wealth share $z$ with respect to time and rewrite the differential equation (recall that $z=V_{r} / V$ ):

$$
\dot{z}=\frac{\dot{V}_{r} V-V_{r} \dot{V}}{V^{2}}=\left(\frac{\dot{V}_{r}}{V_{r}}-\frac{\dot{V}}{V}\right) \frac{V_{r}}{V}=\left(s_{r} r-g\right) z .
$$

It immediately follows that the wealth share is only stable if the Cambridge equation is fulfilled. ${ }^{9}$ Furthermore, it is obvious that the wealth share $z$ rises if $s_{r} r>g$. If this inequality holds, the (percentage) increase in capitalists' wealth is higher than the (percentage) increase in total wealth. Piketty's famous 'fundamental contradiction of capitalism' $r>g$ would thus be a special case of this inequality when $s_{r}=1$, that is, when capitalists accumulate all their income. ${ }^{10}$ In the Post-Keynesian model, the profit rate and the growth rate are not exogenous and constant, but are both endogenously determined and adjust simultaneously until the long-run equilibrium is reached.

From the short-run solutions for $r^{*}$ and $g^{*}$ we see that both the profit rate and the growth rate decrease unambiguously when the wealth share rises. A higher wealth share reduces aggregate demand and thus also the profit rate and the growth rate. As long as $z<z^{* *}$, both rates are higher than their long-run equilibria, that is, $r^{*}>r^{* *}$ and $g^{*}>g^{* *}$. For low wealth shares, the increase in capitalists' wealth is higher than the one in total wealth, and the inequality $s_{r} r>g$ holds. Consequently, capitalists' wealth share rises.

Piketty's 'fundamental contradiction' of capitalism, that the wealth concentration increases if and because $r>g$, is therefore valid in the Post-Keynesian model when $z$ is below its long-term equilibrium. If $r$ is 'significantly greater' than $g$, the wealth share of capitalists will rise. Nevertheless, in contrast to Piketty's view, this can only be a temporary situation. When the wealth share reaches its equilibrium value, the Cambridge equation is fulfilled and the wealth share remains constant.

The profit rate and the growth rate are not the only variables that depend on the wealth share, as discussed in Section 3.2. As long as $z$ goes up, capacity utilization decreases. As a consequence, the wealth-to-income ratio, which is the inverse of the former, rises. The personal income distribution becomes more unequal, since a higher wealth share shifts profits from workers to capitalists.

In the 'transitional phase' - that is, as long as the wealth share is below its long-run equilibrium - the Post-Keynesian model thus predicts a development of the variables in line with Piketty's (2014) empirical data. Both wealth and income distributions become more unequal, the wealth-to-income ratio increases, and economic growth weakens. However, the mechanisms behind these developments differ from Piketty's, and not only will the wealth share eventually reach its stable long-run equilibrium, but all variables are determined within the model and adjust simultaneously.

9. Another (trivial) solution of the differential equation is $z=0$.

10. Piketty (2014, p. 26, emphasis added) writes that 'when the rate of return significantly exceeds the growth rate of the economy ...', which can be interpreted along the lines of the abovementioned inequality (López-Bernardo et al. 2016a). 
Finally, let us briefly look at the effects of a slowdown in growth. In Piketty's view (2014, p. 233), a lower growth rate raises the wealth-to-income ratio, which entails a more unequal income distribution. In the Post-Keynesian model, a fall in the growth rate (which is represented by a lower value for $\beta_{0}$ ), reduces both the long-run profit rate and the long-run growth rate, so that the Cambridge equation is unaffected. It thus has no effect on the distribution of wealth and income. However, it reduces capacity utilization and thus by definition raises the wealth-to-income ratio. In short, while a higher wealth share entails a reduction in the growth rate (due to changes in the saving rates or the profit share), the reverse is not true.

\section{MODEL EXTENSIONS}

The simple version of the model above is analytically tractable, but it arguably does not yet capture the spirit of Piketty's many-faceted analysis. This section therefore discusses three possible extensions to the simple model, which nonetheless retains the Post-Keynesian properties that were derived in the previous section. We introduce: (i) blended income for capitalists; (ii) differential rates of returns across workers and capitalists; and (iii) capital gains.

First, in the basic version of the model, all wages accrued to workers. However, Piketty emphasizes that wages play an important (if diminishing) role even at the very top of the income distribution. Empirically, the share of wages received by capitalists lies between 5 and 10 per cent for the US and most EU countries (Taylor et al. 2015; Ederer and Rehm 2020). In the vein of Palley (2017b), the model can thus be extended by blending not just workers', but also capitalists' income sources, that is, distributing wages between workers and capitalists. As Ederer and Rehm (2020) show, the personal income distribution is then more skewed towards capitalists than in the simple case since workers now receive less (wage) income.

Second, Piketty points to differential rates of return: the higher the wealth owned, the higher the returns on this wealth (Piketty 2014, pp. 447ff; see also Moore 1974; Pasinetti 1974). The reasons for differential returns across the wealth distribution might lie, among other reasons, in more professional wealth management at higher wealth levels, the ability to take higher risks, or a higher likelihood of insider knowledge. Empirical analysis (Ederer and Rehm 2020) finds that the composition of wealth varies between workers and capitalists in particular, with the former holding a larger share of their wealth in low-yield asset classes (in particular, bank deposits). The implication for the distribution of profits is that capitalists receive higher capital income and thus benefit more from the compound-interest effect. We thus distinguish between two asset types within productive wealth: deposits, which we assume for simplicity to be non-interest-bearing; and profit-generating assets, which yield profit income.

Third, capital gains are an important avenue through which retained earnings of firms are distributed to the owners. Even though Piketty does not emphasize them in his theoretical considerations, his empirical results show that they are highly relevant. These capital gains solely depend on the saving rate of firms and can be integrated into a Post-Keynesian model (Palley 2012; López-Bernardo et al. 2016b; Taylor et al. 2017). Since capitalists typically hold a larger share of their wealth in profit-generating assets, a higher saving rate of firms skews the distribution of wealth and income towards them. Furthermore, a higher saving rate of firms can be expected to reduce demand, capacity utilization and growth, since firms by definition have a saving rate equal to one and therefore a higher saving rate than capitalists and workers. 
With these extensions, the analytical solution of the model becomes more complicated than in the basic version. For a detailed stability analysis see Appendix 2. Capitalists' wealth share now depends not only on the saving rates of workers and capitalists and on the profit share, but furthermore on the distribution of wages between workers and capitalists, on their respective shares of wealth held as profit-generating assets, and on the saving rate of firms. The higher capitalists' share of the wage bill, the higher is their wealth share in the long run. The higher the share of capitalists' wealth held in the form of profit-generating assets, the higher is their wealth share (the same holds for workers). The higher the saving rate of firms, the higher is the wealth share of capitalists. This extended model nevertheless exhibits the same short- and long-run dynamic as its basic version.

\section{SIMULATING THE DYNAMICS}

As Section 4 showed, even though the Post-Keynesian wealth model does not corroborate Piketty's theory of a corner solution for the wealth concentration, his empirical analysis is consistent with a transitional phase during which the wealth share of capitalists is below its long-term equilibrium. Ederer and Rehm (2020) show that the wealth shares of capitalists in European countries are currently in fact lower than the long-run equilibrium implied by a parameterized Post-Keynesian model. We therefore focus on the transitional dynamics next, in order to illustrate the behaviour of the extended model from Section 5 in this phase.

The model is calibrated using parameters from the empirical literature (Ederer and Rehm 2020). ${ }^{11}$ As discussed in Section 5, the relevant parameters are the saving rates of workers and capitalists, the share of wealth held as profit-generating assets by workers and by capitalists, the profit share, the distribution parameter for wages (between workers and capitalists) and the saving rate of firms. For details on the parameter values and sources, see Table A1 in Appendix 1.

Figure 1 shows a benchmark simulation using the average parameter values of all ten European countries ${ }^{12}$ for which data are available. It depicts the dynamics of the model $^{13}$ for capacity utilization $u$ in the top-left panel and for the wealth-income ratio $x$ (which, as is clearly visible in the graphic, is the inverse of capacity utilization) at the top-right. In the bottom panels, it shows the profit rate $r$ and the growth rate $g$ on the left, and wealth concentration $z$ and income concentration $\theta$ (as above, measured as the ratio of capitalists' wealth and income to workers' wealth and income, respectively).

There are three main findings. First, the profit rate is always higher than the growth rate. However, the differential decreases over time - if slightly - as the wealth share rises, until it reaches an equilibrium. Second, the model clearly approaches an equilibrium in the long run; the wealth-to-income ratio, wealth and income inequality do not rise indefinitely. Third, however, during a transitional phase over the next 50 to 100 years, the

11. Note that the parameters and starting values for the model indicate that the current level of wealth inequality is below its long-run equilibrium.

12. These countries comprise Austria, Belgium, Cyprus, Spain, Finland, France, Greece, Malta, Portugal and Slovakia.

13. Note that this analysis does not deal with the long-run steady state, which is only reached after more than 200 years. 

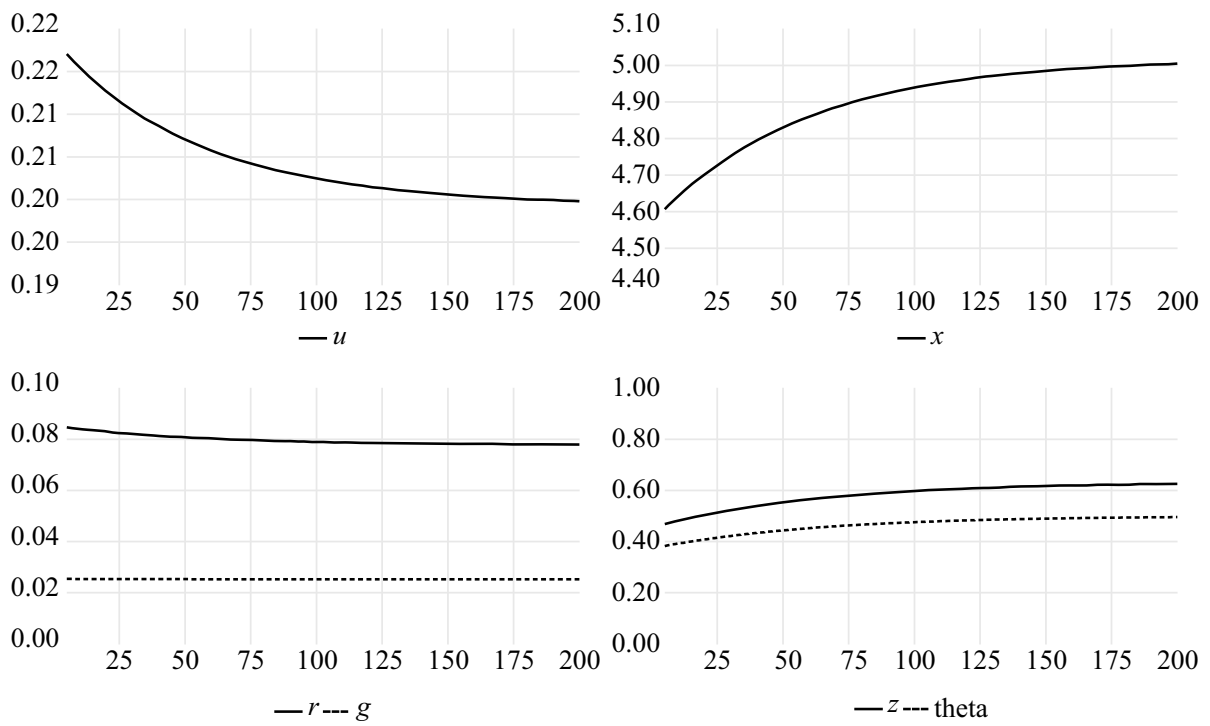

Notes: This graph shows the dynamic in capacity utilization $u$, the wealth-to-income ratio $x$, the profit rate $r$, the growth rate $g$, capitalists' wealth share $z$, and the ratio of capitalists' income to workers' income (personal income distribution) $\theta$. For parameter starting values, see Appendix 1.

Source: Own elaboration.

Figure 1 Short-and long-run dynamics of the Post-Keynesian wealth model for Europe

model points to a steep rise in these variables, and a concomitant fall in capacity utilization.

The first result confirms Piketty's 'first law' of capitalism, $r>g$. This, however, holds by definition in a Post-Keynesian model due to Pasinetti's 'Cambridge equation', $s_{r} r=g$ (except for the unrealistic case in which capitalists do not consume, so that their saving rate is equal to one). The direction of change, however, contrasts with Piketty, who suggests that the differential between the two rates, if anything, will widen. ${ }^{14}$

The second finding is in clear contradiction to Piketty's view (2014, p. 361), namely that ' $[\mathrm{t}] \mathrm{he}$ fact that the return on capital is distinctly and persistently greater than the growth rate is a powerful force for a more unequal distribution'. Leaving aside historical contingencies and caveats, which Piketty (2014, pp. 361ff) is careful to discuss and include in his theoretical predictions, Piketty's bare-bones model predicts an ever-increasing wealth share, and thus eventually a corner solution for the concentration of wealth, in which a tiny elite owns all wealth. In contrast, our calibrated simulation confirms the theoretical finding from our analytical model, namely that the wealth share held by capitalists usually stabilizes at an interior solution. In the PostKeynesian world, both workers and capitalists own a stable share of wealth.

Our third finding bridges the gap between a Post-Keynesian analysis and Piketty's empirical findings, or, put differently, it provides an analytical underpinning to

14. Note that if we assumed an exogenously rising profit share, then the model would temporarily raise the difference between $r$ and $g$. 
Piketty's work. During the transition phase from the current state towards the long-run equilibrium, all variables exhibit the development described by Piketty: the share of wealth owned by capitalists - the Post-Keynesian equivalent to Piketty's 'elite' defined by percentiles of the wealth distribution - rises unequivocally and by significant levels from under 50 per cent to more than 60 per cent. Similarly, the wealth-to-income ratio increases to around 5. In addition, personal income inequality increases, that is, the ratio of capitalists' income to workers' income rises from just below 40 per cent to roughly 50 per cent. As with wealth, Piketty measures these as income share of percentiles of the income distribution. To conclude, our simulation reproduces the main messages of Piketty's (2014) book: the wealth-to-income ratio, the wealth concentration, and personal income inequality will all increase, if capitalism is left to its own devices.

Figure 2 shows the effect of a rise in 'animal spirits', that is, the exogenous component of the investment function $\beta_{0}$. Piketty does not focus on the growth regime in too much detail, and his natural rate of growth of course does not directly map to our endogenous growth rate. Nonetheless, here, too, our findings from the calibrated model are in line with his broad predictions - and, as expected, with Post-Keynesian models: if autonomous investment increases, the profit rate and the growth rate rise, as does capacity utilization, and therefore the wealth-to-income ratio falls. However, the simulations also make clear that a change in autonomous investment has only transient effects on the distribution of wealth. In the long-run, capitalists' wealth share approaches the same value as in the baseline simulation. The equilibrium value for the wealth share does not depend on the growth rate since the profit rate also increases endogenously, so that the Cambridge equation is fulfilled at the same value for $z$ as before.
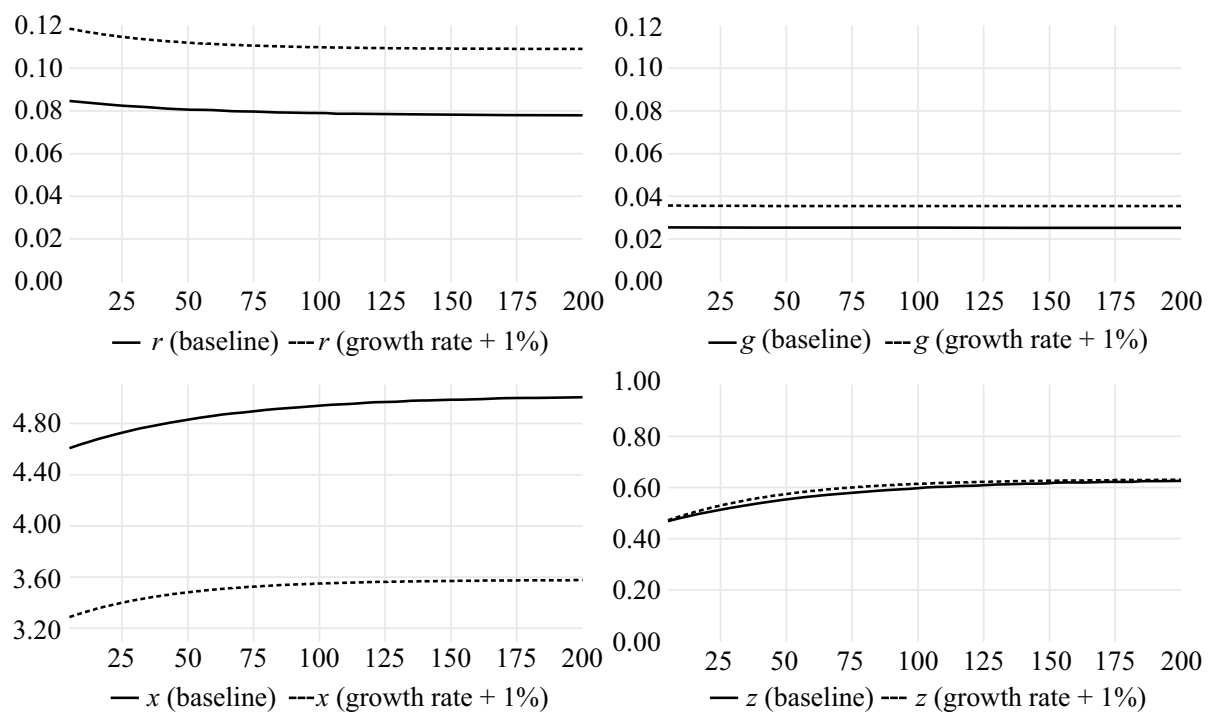

Notes: This graph shows the dynamic in the profit rate $r$, the growth rate $r$, the wealth-to-income ratio $x$, and capitalists' wealth share $z$ following an increase in autonomous investment, compared to a baseline scenario. For parameter starting values, see Appendix 1.

Source: Own elaboration.

Figure 2 Effects of an increase in the growth rate on short- and long-run dynamics of the Post-Keynesian wealth model in Europe 


\section{THE EFFECTS OF A WEALTH TAX}

Piketty's (2014, p. 532) solution for his predicted increasing wealth concentration and rising wealth-to-income ratio is a global wealth tax. Although Post-Keynesians criticize the proposal for being utopian (Palley 2014), it is nevertheless interesting to investigate the effects of such a wealth tax in the Post-Keynesian model.

Piketty (2014, p. 571) (tentatively) suggests a tax of 0.1 per cent on wealth up to $€ 200000,0.5$ per cent up to $€ 1$ million, 1 per cent up to $€ 5$ million, 2 per cent up to $€ 1$ billion, and 5 per cent (to 10 per cent) on wealth greater than $€ 1$ billion. For simplicity, we use the average for the lower two brackets ( 0.3 per cent) as workers' average tax rate and the average of the higher three tax brackets ( 4.3 per cent) as capitalists' tax rate. Furthermore, we formulate the tax as a flat rate $t$ on the total wealth of both workers and capitalists and we assume that tax earnings are spent as government consumption to maintain the stock-flow consistency of the model. ${ }^{15}$ Income of capitalists and workers becomes

$$
\begin{gathered}
Y_{r}=z R-t_{r} V_{r} \\
Y_{w}=W+(1-z) R-t_{w} V_{w} .
\end{gathered}
$$

For the dynamic equations, see Appendix 3.

Figure 3 shows that the wealth tax redistributes income from capitalists (with a higher saving rate) to workers. It therefore raises capacity utilization and simultaneously reduces the wealth-income ratio, while the growth rate and the profit rate also rise. Most importantly however, from Piketty's point of view, the wealth share of capitalists falls noticeably, from roughly 62 per cent in the baseline scenario to about 50 per cent. That is, a wealth tax as suggested by Piketty would neutralize the rise in wealth inequality predicted by the model. This reduction in the wealth share is permanent, as long as the tax is imposed periodically. Conversely, one-off levies only have a transitory effect as the wealth concentration returns to its longrun equilibrium.

Other taxes that reduce the income of capitalists and thus dampen their ability to accumulate wealth, such as an inheritance tax or income taxes for capitalists, are fungible to a wealth tax; they will lead to the same effects as the ones described in Figure 3. In fact, in the Post-Keynesian model, these different taxes can easily be calibrated to yield identical results. If wealth is passed on to the next generation every 25 years, an inheritance tax of 60 per cent has on average the same incidence as a general (yearly) wealth tax of 2.4 per cent (which is our average tax rate). Similarly, since capital income is a share of wealth, taxing capital income is equivalent to taxing wealth directly. Introducing a tax on capital income of approximately 30 per cent is consequently roughly equivalent to a yearly wealth tax of 2.4 per cent, given that the profit rate in the simulation is about 8 per cent. ${ }^{16}$

15. Another way to balance the budget would be to spend all tax revenue on monetary transfers. Transfers directly increase the income of households and have a distributive effect themselves, given that workers and capitalists benefit differently from them. Public consumption on the other hand has no direct distributive effect in the model, which allows us to isolate the sole effect of Piketty's tax rates.

16. However, it should be noted that this back-of-an-envelope calculation does not take into account that an income tax does not capture capital gains. 
212 Review of Keynesian Economics, Vol. 8 No. 2
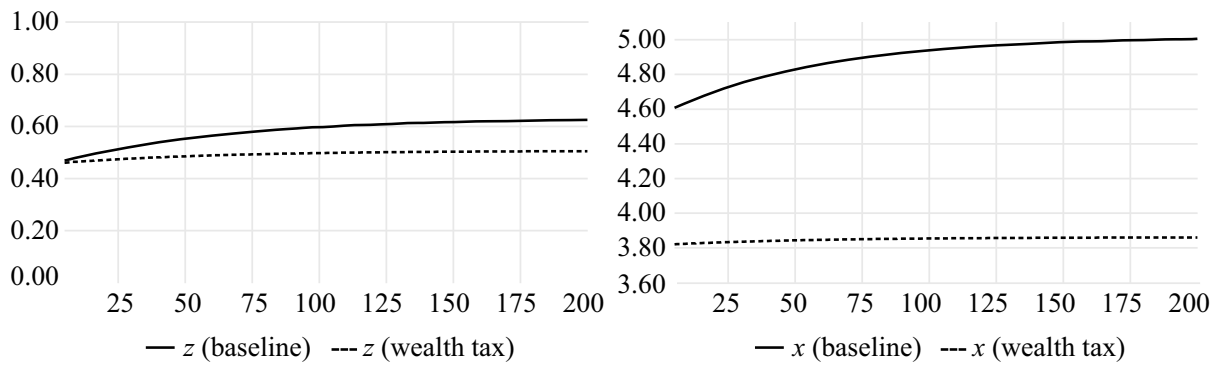

Notes: This graph shows the dynamic in the wealth-to-income ratio $x$, and capitalists' wealth share $z$ for a wealth tax of 0.3 per cent on workers' and 4.3 per cent of capitalists' wealth, compared to a baseline scenario. For parameter starting values, see Appendix 1.

Source: Own elaboration.

Figure 3 Effects of a wealth tax on short-and long-run dynamics of the Post-Keynesian wealth model in Europe

\section{CONCLUSION}

This paper bridges the gap between a Post-Keynesian analysis and Piketty's (2014) empirical insights. We develop a Post-Keynesian model with an endogenous distribution of wealth between workers and capitalists, and extend it by including blended wage and capital income of both workers and capitalists, differential returns on assets between workers and capitalists, and capital gains. Since the transition phase to the long-run equilibrium matters in the real world, we focus on the short- and long-run dynamics of the model, and evaluate Piketty's proposal of a wealth tax.

If Piketty's main theoretical prediction ( $r>g$ leads to rising wealth inequality) is taken to its radical conclusion, then a small elite will own all wealth if capitalism is left to its own devices. Our model permits such a corner solution of all wealth held by capitalists, but usually economies will show a stable long-run wealth distribution in which workers have a positive wealth share. In such an interior equilibrium, the wealth-to-income ratio is stable, and there is a (stable and positive) gap between the profit rate and the growth rate, which is given by the Cambridge equation. The specific level of the equilibrium wealth distribution between workers and capitalists depends on their saving rates, the profit share, the share of wage income that accrues to capitalists, the differential returns on wealth for the two household groups, and the saving rate of firms.

We therefore provide an alternative to the simple version of Piketty's theoretical long-run equilibrium. However, like Piketty (2014), Post-Keynesians are interested in the real world of living generations; we therefore show that the model has a transitional phase, that is, when the wealth share of capitalists is below its long-term equilibrium. During this transition phase, the model behaves according to Piketty's (2014) empirical findings for high-income countries since the 1980s. In this situation, the wealth share of capitalists increases endogenously, the wealth-to-income ratio rises, the differential between the profit rate and the growth rate gradually decreases (but is always higher than the long-term gap), and income inequality rises. Consistent with Keynesian logic, a rising wealth share reduces aggregate demand and thus capacity utilization and growth. 
For this transition phase, the paper thus provides theoretical foundations to Piketty's abundant and convincing empirical findings, and it permits us to model the long-run evolution of inequality. Concretely, our simulations show that wealth inequality in Europe - as measured by capitalists' wealth share - would rise from well under 50 per cent to more than 60 per cent. This level differs substantially across individual countries, as Ederer and Rehm (2020) show.

Piketty (2014) emphasizes both the determinants and the effects of these pernicious empirical developments in detail, and carefully weighs counter-effects to his theoretical finding of capitalism's inherent tendency to an increasing wealth concentration. Piketty, like many Post-Keynesians, worries that the world of increasing inequality, which his data describe, might be prone to upheavals, social unrest and war. This is why Piketty (2014) suggests a wealth tax to address the increasing concentration of wealth. We find that the introduction of a permanent wealth tax at levels suggested by Piketty (or, equivalently, a suitable inheritance tax or capital income tax) can indeed neutralize the rise in wealth inequality predicted by the model. It reduces the equilibrium value for the wealth share owned by capitalists in Europe - and thus the wealth concentration - to 50 per cent. It also reduces the wealth-to-income ratio and dampens income inequality.

There are a number of interesting avenues for future work. First, expanding the analysis to other countries, such as the US, is an obvious next step. Second, endogenizing the profit share and working through the stability aspects of such a model might provide a valuable insight into potential 'Piketty dynamics' in a Keynesian framework. Third, delving into the policy research might yield more detailed information on the relative merits of a wealth tax versus an inheritance tax or capital income taxes. Finally, investigating the dynamics of the distribution of wealth globally - as well as the redistributive effects of a global wealth tax - would be very interesting, but is unfortunately severely constrained by data availability.

\section{REFERENCES}

Barbosa-Filho, N. and L. Taylor (2006), 'Distributive and demand cycles in the US economy: a structuralist Goodwin model', Metroeconomica, 57(3), 389-411.

Bhaduri, A. and S. Marglin (1990), 'Unemployment and the real wage: the economic basis for contesting political ideologies', Cambridge Journal of Economics, 14(4), 375-393.

Carvalho, L. and A. Rezai (2016), 'Personal income inequality and aggregate demand', Cambridge Journal of Economics, 40(2), 491-505.

Darity, W.A. (1981), 'The simple analytics of Neo-Ricardian growth and distribution', The American Economic Review, 71(5), 978-993.

Duménil, G. and D. Lévy (2014), The Economics and Politics of Thomas Piketty's Theses II: An Alternative Reading of the History of Capitalism, Unpublished manuscript, available at: http://www.cepremap.fr/membres/dlevy/dle2014g.htm.

Dutt, A.K. (1990), 'Growth, distribution and capital ownership: Kalecki and Pasinetti revisited', in B. Dutta, S. Gangopadhyay, D. Mookherjee and D. Ray (eds), Economic Theory and Policy: Essays in Honour of Dipak Banerjee, Bombay: Oxford University Press, pp. 130-145.

Ederer, S. and M. Rehm (2020), 'Will wealth become more concentrated in Europe? Evidence from a calibrated Post-Keynesian model', Cambridge Journal of Economics, 44(1), 55-72.

Felipe, J. and J.S.L. McCombie (2013), The Aggregate Production Function and the Measurement of Technical Change: 'Not Even Wrong', Cheltenham, UK and Northampton, MA: Edward Elgar Publishing.

Galbraith, J.K. (2014), 'Unpacking the first fundamental law', Real-World Economics Review, 69(7), 145-148. 
Harcourt, G.C. (1972), Some Cambridge Controversies in the Theory of Capital, Cambridge, UK: Cambridge University Press.

Kalecki, M. (1971), Selected Essays on the Dynamics of the Capital Economy, Cambridge, UK: Cambridge University Press.

Kiefer, D. and C. Rada (2015), 'Profit maximising goes global: the race to the bottom', Cambridge Journal of Economics, 39(5), 1333-1350, available at: https://doi.org/10.1093/cje/ beu040.

King, J.E. (2017), 'The literature on Piketty', Review of Political Economy, 29(1), 1-17, doi: $10.1080 / 09538259.2016 .1173425$.

Lavoie, M. (2009), 'Cadrisme within a Kaleckian model of growth and distribution', Review of Political Economy, 21(3), 371-393.

Lavoie, M. and E. Stockhammer (2013), 'Wage-led growth: concepts, theories and policies', in M. Lavoie and E. Stockhammer (eds), Wage-Led Growth: An Equitable Strategy for Economic Recovery, Basingstoke, UK: Palgrave Macmillan, pp. 13-39.

López-Bernardo, J., F. López-Martínez and E. Stockhammer (2016a), 'A Post-Keynesian response to Piketty's "Fundamental contradiction of capitalism"', Review of Political Economy, 28(2), 190-204.

López-Bernardo, J., E. Stockhammer and F. López-Martínez (2016b), 'A Post-Keynesian theory for Tobin's $q$ in a stock-flow consistent framework', Journal of Post Keynesian Economics, 39(2), 256-285.

Meade, J. (1964), 'The outcome of the Pasinetti-process: a note', The Economic Journal, 76(301), 161-165.

Michl, T.R. (2014), 'Capitalists, workers and Thomas Piketty's Capital in the 21st Century', Review of Political Economy, 28(2), 205-219.

Moore, B.J. (1974), 'The Pasinetti paradox revisited', The Review of Economic Studies, 41(2), 297-299.

Palley, T. (2012), 'Wealth and wealth distribution in the Neo-Kaleckian growth model', Journal of Post Keynesian Economics, 34(3), 453-474.

Palley, T. (2014), 'The accidental controversialist: deeper reflections on Thomas Piketty's "Capital", available at: http://www.thomaspalley.com/?p=422.

Palley, T. (2017a), 'Wage- vs. profit-led growth: the role of the distribution of wages in determining regime character', Cambridge Journal of Economics, 41(1), 49-61.

Palley, T. (2017b), 'Inequality and growth in Neo-Kaleckian and Cambridge growth theory', Review of Keynesian Economics, 5(2), 146-169.

Pasinetti, L. (1962), 'Income distribution and rate of profit in relation to the rate of economic growth', Review of Economic Studies, 29(4), 267-279.

Pasinetti, L. (1974), Growth and Income Distribution: Essays in Economic Theory, Cambridge, UK: Cambridge University Press.

Petach, L. and D. Tavani (2020), 'Income shares, secular stagnation, and the long-run distribution of wealth', Metroeconomica, 71(1), 235-255.

Piketty, T. (2014), Capital in the Twenty-First Century, Cambridge, MA: The Belknap Press of Harvard University Press.

Piketty, T. and G. Zucman (2014), 'Capital is back: wealth-income ratios in rich countries 1700-2010', Quarterly Journal of Economics, 129(3), 1255-1310.

Rehm, M. and M. Schnetzer (2015), 'Property and power: lessons from Piketty and new insights from the HFCS', European Journal of Economics and Economic Policies, 12(2), 204-219.

Rowthorn, R. (2014), 'A note on Piketty's Capital in the Twenty-First Century', Cambridge Journal of Economics, 38(5), 1275-1284, available at: https://doi.org/10.1093/cje/beu031.

Samuelson, P.A. and F. Modigliani (1966), 'The Pasinetti paradox in Neoclassical and more general models', The Review of Economic Studies, 33(4), 269-301.

Stockhammer, E. and S. Ederer (2008), 'Demand effects of the falling wage share in Austria', Empirica, 35(5), 481-502, available at: http://www.springer.com/10663.

Stockhammer, E., Ö. Onaran and S. Ederer (2009), 'Functional income distribution and aggregate demand in the Euro area', Cambridge Journal of Economics, 33(1), 139-159. 
Taylor, L. (2014), 'The triumph of the Rentier? Thomas Piketty vs. Luigi Pasinetti and John Maynard Keynes', International Journal of Political Economy, 43(3), 4-17.

Taylor, L., Ö. Ömer and A. Rezai (2015), 'Wealth concentration, income distribution, and alternatives for the USA', INET Working Paper No 17, available at: https://www.ineteconomics. org/uploads/papers/WP17-Lance-Taylor-Income-dist-wealth-concentration-0915.pdf.

Taylor, L., A. Rezai, R. Kumar, N. Barbosa and L. Carvalho (2017), 'Wage increases, transfers, and the socially determined income distribution in the USA', Review of Keynesian Economics, 5(2), 259-275.

Van Treeck, T. (2015), ' $r>g$ : why the "Piketty debate" unsettles Germany's economic experts', CESifo Forum, 16(1), 26-34.

Zamparelli, L. (2017), 'Wealth distribution, elasticity of substitution, and Piketty: an "anti-dual" Pasinetti economy', Metroeconomica, 68(4), 927-946. 
216 Review of Keynesian Economics, Vol. 8 No. 2

\section{APPENDIX 1 PARAMETER VALUES}

Table A1 Parameter values for the model calibration, average over countries

\begin{tabular}{lll}
\hline Parameter & Value & Source \\
\hline$s_{w}$ & 0.07 & Ederer and Rehm 2020; Data: EHBS \\
$s_{r}$ & 0.24 & Ederer and Rehm 2020; Data: EHBS \\
$\pi$ & 0.39 & Ederer and Rehm 2020; Data: HFCS \\
$\alpha$ & 0.06 & Ederer and Rehm 2020; Data: HFCS \\
$\gamma_{w}$ & 0.49 & Ederer and Rehm 2020; Data: HFCS \\
$\gamma_{r}$ & 0.91 & Ederer and Rehm 2020; Data: HFCS
\end{tabular}

Notes: Rows refer to: (1) $s_{w}$ saving rate of workers; (2) $s_{r}$ saving rate of capitalists; (3) $\pi$ profit share; (4) $\alpha$ share of capitalists in the wage bill; (5) $\gamma_{w}$ share of workers' wealth held in profit-generating assets; (6) $\gamma_{r}$ share of capitalists' wealth held in profit-generating assets. In order to reproduce the empirical results of Ederer and Rehm (2020), we set the parameter for the saving rate of firms equal to zero. Since the empirical value of this parameter is usually higher, the long-run values of the simulations are on the conservative side.

\section{APPENDIX 2 EXTENDED MODEL}

Table A2 Transaction flow matrix in the extended model

\begin{tabular}{|c|c|c|c|c|c|c|}
\hline & \multicolumn{2}{|c|}{ Households } & \multicolumn{2}{|c|}{ Firms } & \multirow{2}{*}{$\frac{\text { Banks }}{\text { Capital }}$} & \multirow[b]{2}{*}{ Total } \\
\hline & Workers & $\overline{\text { Capitalists }}$ & Current & $\overline{\text { Capital }}$ & & \\
\hline Consumption & $-C_{w}$ & $-C_{r}$ & $+C$ & - & - & 0 \\
\hline Investment & - & - & $+I$ & $-I$ & - & 0 \\
\hline Wages & $+W_{w}$ & $+W_{r}$ & $-W$ & - & - & 0 \\
\hline Profits & $+R_{w}$ & $+R_{r}$ & $+R$ & $+R_{f}$ & - & 0 \\
\hline Equity & $-\Delta E_{w}$ & $-\Delta E_{r}$ & - & $+\Delta E$ & - & 0 \\
\hline Deposits & $-\Delta D_{w}$ & $-\Delta D_{r}$ & - & - & $+\Delta D$ & 0 \\
\hline Loans & - & - & - & $+\Delta L$ & $-\Delta L$ & 0 \\
\hline Total & 0 & 0 & 0 & 0 & 0 & 0 \\
\hline
\end{tabular}

Source: Own elaboration.

Table A3 Balance-sheet matrix in the extended model

\begin{tabular}{|c|c|c|c|c|c|}
\hline & \multicolumn{2}{|c|}{ Households } & \multirow[b]{2}{*}{ Firms } & \multirow[b]{2}{*}{ Banks } & \multirow[b]{2}{*}{ Total } \\
\hline & Workers & Capitalists & & & \\
\hline Capital & - & - & $+K$ & - & $+K$ \\
\hline Equity & $+E_{w}$ & $+E_{r}$ & $-E$ & - & 0 \\
\hline Deposits & $+D_{w}$ & $+D_{r}$ & - & $-D$ & 0 \\
\hline Loans & - & - & $-L$ & $+L$ & 0 \\
\hline Wealth & $-V_{w}$ & $-V_{r}$ & $-V_{f}$ & - & $-V$ \\
\hline Total & 0 & 0 & 0 & 0 & 0 \\
\hline
\end{tabular}

Source: Own elaboration. 
Retained profits:

$$
R_{f}=\eta R
$$

Disposable income:

$$
\begin{gathered}
Y_{w}=(1-\alpha) W+\frac{\gamma_{w}(1-z)}{\gamma_{w}(1-z)+\gamma_{r} z}(1-\eta) R \\
Y_{r}=\alpha W+\frac{\gamma_{r} z}{\gamma_{w}(1-z)+\gamma_{r} z}(1-\eta) R .
\end{gathered}
$$

Wealth dynamic:

$\dot{z}=\frac{\dot{V}_{r}}{V}-g z=\left\{s_{r}\left[(1-\pi) \alpha+\frac{\gamma_{r} z}{\gamma_{w}(1-z)+\gamma_{r} z}(1-\eta) \pi\right]+\frac{\gamma_{r} z}{\gamma_{w}(1-z)+\gamma_{r} z} \eta \pi\right\} u-g z$.

Stability analysis: the short-run solution for capacity utilization (that is, the IS curve) is

$$
u^{*}=\frac{\beta_{0}+\beta_{2} \pi}{s-\beta_{1}}
$$

with $s=s_{w}\left[(1-\alpha)(1-\pi)+\frac{\gamma_{w}(1-z)}{\gamma_{w}+\left(\gamma_{r}-\gamma_{w}\right) z}(1-\eta) \pi\right]+s_{r}\left[\alpha(1-\pi)+\frac{\gamma_{r} z}{\gamma_{w}+\left(\gamma_{r}-\gamma_{w}\right) z}(1-\eta) \pi\right]$,

where $s$ is an increasing function of $z$ and positive for $z=0$ if $s_{w}[(1-\alpha)(1-\pi)+$ $(1-\eta) \pi]+s_{r} \alpha(1-\pi)>\beta_{1} \cdot{ }^{17}$ Furthermore, $u$ decreases when $z$ increases, and approaches a constant positive value for $z \rightarrow \infty$. Thus, $u$ is positive for all (positive) values of $z$.

Substituting $g=s u$ into equation (A4) yields $\dot{z}=A u$ with

$$
\begin{aligned}
A= & s_{r}\left[\alpha(1-\pi)+\frac{\gamma_{r} z}{\gamma_{w}+\left(\gamma_{r}-\gamma_{w}\right) z}(1-\eta) \pi\right](1-z) \\
& -s_{w}\left[(1-\alpha)(1-\pi)+\frac{\gamma_{w}(1-z)}{\gamma_{w}+\left(\gamma_{r}-\gamma_{w}\right) z}(1-\eta) \pi\right] z+\frac{\gamma_{r} z}{\gamma_{w}+\left(\gamma_{r}-\gamma_{w}\right) z} \eta \pi .
\end{aligned}
$$

Since $u$ is always positive (see above), the sign of $\dot{z}$ uniquely depends on $A$.

We will now consider the two corner solutions of $z=0$ and $z=1$, that is, the 'dual equilibrium' (Samuelson and Modigliani 1966) and the 'anti-dual equilibrium' (Darity 1981; see also, for example, Zamparelli 2017), and the interior solution, that is, the 'Pasinetti equilibrium' in which the wealth share of capitalists is smaller than one.

Since $A>0$ for $z=0, \dot{z}$ is also positive and the wealth concentration rises. Consequently, the model structure precludes a dual equilibrium. ${ }^{18}$

17. Since $s_{0}=s_{w}[(1-\alpha)(1-\pi)+(1-\eta) \pi]+s_{r} \alpha(1-\pi)$ is the value of $s$ at $z=0$ and $s$ is an increasing function of $z$, this condition is actually weaker than the Keynesian stability condition $s-\beta_{1}>0$, which is usually assumed to hold in all Kaleckian models (Dutt 1990).

18. Except when $s_{w}=s_{r}, \gamma_{w}=\gamma_{r}$ and $\alpha=0$, or in the trivial case when capitalists do not save at all. 
The existence of a 'Pasinetti equilibrium' depends on whether $A=0$ for a value $z<1$, or equivalently, $A<0$ for $z=1$ (since $A>0$ for $z=0$ ). Plugging these into equation (A6), this condition translates into

$$
\eta<\frac{s_{w}(1-\alpha)(1-\pi)}{\pi} .
$$

If this condition is not fulfilled, $\dot{z}$ is still positive for $z=1$ and we get an anti-dual equilibrium, in which capitalists hold all the wealth. Furthermore, it is clear from equation (A6) that this condition is always fulfilled if firms do not save $(\eta=0)$. In this case, there cannot be an anti-dual equilibrium.

Graphically, the dynamic equation for $z$ takes the form shown in Figure A1 if we use the parameters from our simulations. The economically meaningful equilibrium is clearly stable since the curve crosses the horizontal axis from above. We are thus in a Pasinetti equilibrium with a capitalists' wealth share smaller than one.

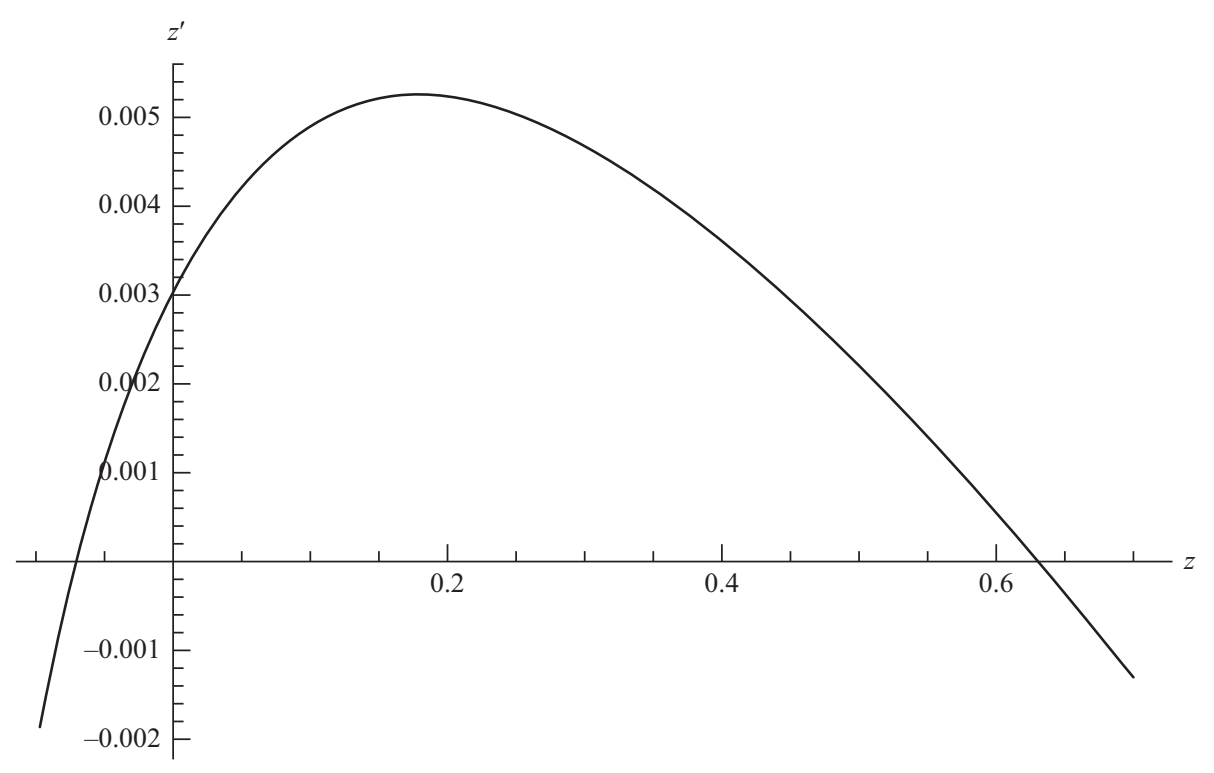

Source: Own elaboration.

Figure A1 Stability analysis of the differential wealth equation in the extended model 


\section{APPENDIX 3 BASIC MODEL WITH A (PROGRESSIVE) WEALTH TAX}

Table A4 Stocks and flows in the model with a wealth tax

\begin{tabular}{|c|c|c|c|c|c|c|}
\hline & \multicolumn{2}{|c|}{ Households } & \multicolumn{2}{|c|}{ Firms } & \multirow{2}{*}{$\frac{\text { State }}{\text { Current }}$} & \multirow[b]{2}{*}{ Tota } \\
\hline & Workers & Capitalists & Current & Capital & & \\
\hline Consumption & $-C_{w}$ & $-C_{r}$ & $+C$ & - & $+C_{g}$ & 0 \\
\hline Investment & - & - & $+I$ & $-I$ & - & 0 \\
\hline Wages & $+W$ & - & $-W$ & - & - & 0 \\
\hline Profits & $+R_{w}$ & $+R_{r}$ & $-R$ & - & - & 0 \\
\hline$\underline{\text { Taxes }}$ & $-T_{w}$ & $-T_{r}$ & - & - & $+T$ & 0 \\
\hline Wealth & $-\Delta V_{w}$ & $-\Delta V_{r}$ & - & $+\Delta K$ & 0 & 0 \\
\hline Total & 0 & 0 & 0 & 0 & 0 & 0 \\
\hline
\end{tabular}

Source: Own elaboration.

Wealth dynamic:

$$
\begin{gathered}
\dot{z}=\left[s_{r}\left(r-t_{r}\right)-g\right] z \\
z^{*}=\frac{\left(\beta_{0}+\beta_{2} \pi\right)\left(s_{r} \pi-s_{w}\right)+\beta_{1}\left(s_{r} t_{r}-s_{w} t_{w}\right)-s_{w} s_{r}\left(t_{r}-t_{w} \pi\right)}{\left(\beta_{0}+\beta_{2} \pi\right)\left(s_{r}-s_{w}\right) \pi+\beta_{1}\left(s_{r} t_{r}-s_{w} t_{w}\right)-s_{w} s_{r} \pi\left(t_{r}-t_{w}\right)} .
\end{gathered}
$$

